\title{
The prognostic value of BRCA1 promoter methylation in early stage triple negative breast cancer
}

\author{
Priyanka Sharma ${ }^{1+*}$, Shane R. Stecklein ${ }^{2,5 \dagger}$, Bruce F. Kimler ${ }^{3,4}$, Geetika Sethi ${ }^{2,6}$, Brian K. Petroff ${ }^{1,4}$, Teresa A. Phillips ${ }^{1,4}$, Ossama W. Tawfik ${ }^{2,5}$, \\ Andrew K. Godwin 2,5 and Roy A. Jensen ${ }^{2,5}$ \\ *Correspondence: psharma2@kumc.edu

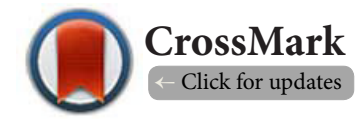 \\ 'These authors contributed equally to this work. \\ 'Division of Hematology/Oncology, Department of Internal Medicine, University of Kansas Medical Center, Kansas City, Kansas, USA. \\ ${ }^{2}$ Department of Pathology and Laboratory Medicine, University of Kansas Medical Center, Kansas City, Kansas, USA. \\ ${ }^{3}$ Department of Radiation Oncology, University of Kansas Medical Center, Kansas City, Kansas, USA. \\ ${ }^{4}$ Breast Cancer Prevention Center, University of Kansas Medical Center, Kansas City, Kansas, USA. \\ ${ }^{5}$ The University of Kansas Cancer Center, University of Kansas Medical Center, Kansas City, Kansas, USA. \\ ${ }^{6}$ Department of Biochemistry and Molecular Biology, Drexel University College of Medicine, Philadelphia, Pennsylvania, USA.
}

\begin{abstract}
Introduction: Methylation of the BRCA1 promoter is frequent in triple negative breast cancers (TNBC) and results in a tumor phenotype similar to BRCA1-mutated tumors. BRCA1 mutation-associated cancers are more sensitive to DNA damaging agents as compared to conventional chemotherapy agents. It is not known if there is an interaction between the presence of BRCA1 promoter methylation (PM) and response to chemotherapy agents in sporadic TNBC. We sought to investigate the prognostic significance of $B R C A 1$ PM in TNBC patients receiving standard chemotherapy.

Methods: Subjects with stage I-III TNBC treated with chemotherapy were identified and their formalin-fixed paraffin-embedded (FFPE) tumor specimens retrieved. Genomic DNA was isolated and subjected to methylation-specific PCR (MSPCR).

Results: DNA was isolated from primary tumor of 39 subjects. BRCA1 PM was detected in $30 \%$ of patients. Presence of BRCA1 PM was associated with lower $B R C A 1$ transcript levels, suggesting epigenetic BRCA1 silencing. All patients received chemotherapy (anthracycline:90\%, taxane:69\%). At a median follow-up of 64 months, $46 \%$ of patients have recurred and 36\% have died. On univariate analysis, African-American race, node positivity, stage, and BRCA1 PM were associated with worse RFS and OS. Five year OS was $36 \%$ for patients with BRCA1 PM vs. $77 \%$ for patients without BRCA1 PM (p=0.004). On multivariable analysis, BRCA1 PM was associated with significantly worse RFS and OS.
\end{abstract}

Conclusions: We show that BRCA1 PM is common in TNBC and has the potential to identify a significant fraction of TNBC patients who have suboptimal outcomes with standard chemotherapy.

Keywords: Triple negative breast cancer, BRCA1 promoter methylation, prognosis, chemosensitivity, biomarker

\section{Introduction}

Triple negative breast cancer (TNBC) is defined by the lack of expression of estrogen receptor (ER) and progesterone receptor (PR), and absence of ERBB2 (HER2) over expression and/or gene amplification and is associated with poor longterm outcomes compared to other breast cancer subtypes [1-3]. Despite receiving standard cytotoxic chemotherapy, a significant proportion (approximately 30-40\%) of patients with early stage TNBC develop metastatic disease and succumb to their cancer [4-6]. To improve outcomes for this subtype, we not only need novel targeted agents, but also need to identify predictors of response/resistance to standard chemotherapy. $B R C A 1$ dysfunction may have the potential to serve both as a therapeutic target and as prognostic marker of response to targeted therapy in TNBC.

$B R C A 1$ is a classic tumor suppressor gene and the loss of the wild-type allele [loss of heterozygosity ( $\mathrm{LOH})$ ] is required for tumorigenesis in germline mutation carriers. Sporadic TNBC and $B R C A 1$ germline mutation-associated breast cancers share many histopathologic and molecular features; however, only $10-20 \%$ of TNBCs harbor germline BRCA1 mutation [7-9]. The phenotypic and molecular similarities between BRCA1 mutationassociated and sporadic TNBC have led many to surmise that sporadic TNBCs may involve BRCA1 pathway dysfunction through non-mutational means. Epigenetic inactivation of tumor suppressor genes by the aberrant addition of methyl groups in their CpG-rich regulatory regions (promoter CpG islands) is a common hallmark of human tumors. Hypermethylation of the $B R C A 1$ promoter has been proposed as one of the mechanisms for functionally inactivating the $B R C A 1$ gene in breast cancers and this epigenetic inactivation of $B R C A 1$ is associated with a gene expression profile similar to that of inherited $B R C A 1$ 
mutation-associated breast cancer [10-12].

$B R C A 1$ promoter methylation (PM) is observed in $20-60 \%$ of sporadic TNBC and may be an important mechanism contributing to the loss of $B R C A 1$ function in sporadic TNBC $[11,13-15]$. Methylation specific PCR (MSPCR) has been utilized to detect hypermethylation of the areas of interest in the $\mathrm{CpG}$ islands of the $B R C A 1$ promoter by many investigators $[10,11,14]$. MSPCR is relatively inexpensive and can be performed on genomic DNA derived from formalin-fixed paraffin-embedded (FFPE) tissue, and thus has the potential of being easily applied to clinical settings.

$B R C A 1$ plays a crucial role in homologous recombinationdependent DNA double-strand break and interstrand crosslink repair, and $B R C A 1$-deficient cells are particularly susceptible to the DNA damaging agents like platinum compounds $[16,17]$. Observational studies and small neoadjuvant studies have also suggested that BRCA1 mutation-associated breast cancers may be more sensitive to platinum agents as compared to sporadic TNBC $[\mathbf{8}, \mathbf{1 8}]$. It is not known if epigenetic silencing of $B R C A 1$ via promoter methylation in sporadic TNBC impacts response to chemotherapy. Several prior studies have evaluated BRCA1 PM in TNBC but, have shown conflicting results in regards to prognostic impact of $B R C A 1$ PM in TNBC $[15,19,20-22]$. These prior studies, differ in the methodology used for detection of BRCA1 PM, do not uniformly include analysis of $B R C A 1$ expression (to confirm epigenetic gene silencing) and include TNBC patients treated with various different chemotherapy regimens thus, limiting the ability of cross study comparisons. The purpose of this study was to investigate the prognostic significance of epigenetic BRCA1 silencing in early stage TNBC patients treated with modern chemotherapy (anthracyline and taxane).

\section{Methods \\ Ethics statement}

This study was approved by the Institutional Review Board (IRB) at the University of Kansas Medical Center, Kansas City, Kansas, USA, and was exempt from the informed consent process pursuant to 45 CFR $46.11(d)$.

\section{Patients}

Subjects with early stage (TNM stage I-III) TNBC who had definitive surgery at the University of Kansas Hospital, were treated with adjuvant/neoadjuvant chemotherapy, and for whom tumor specimens were available in our pathology archives were identified. TNBC was defined as negative ER, PR, and HER2 status. Immunohistochemical nuclear staining of less than or equal to $1 \%$ was considered a negative result for ER and PR (in accordance with 2010 ASCO/CAP guidelines). HER2-negative tumors were defined as 0 or $1+$ on IHC staining and/or lack of gene amplification found on FISH testing (ratio less than 2.0).

Under an IRB-approved protocol, 106 patients with stage I-III TNBC who had definitive surgery at our institution between
1996-2008 were identified. 29/106 patients did not receive any systemic adjuvant/neoadjuvant chemotherapy and another 29 patients had incomplete information on follow up. FFPE tumor tissue samples were retrieved from the pathology archives for the remaining 48 patients. Each tumor specimen was evaluated by a pathologist to confirm the presence of invasive disease and only samples with $>50 \%$ invasive cancer were included in the analysis. Thirty-nine of the 48 patients had an archived tissue block available with adequate invasive cancer and formed the study cohort (Figure 1). For patients who received neoadjuvant chemotherapy, the biopsy specimen obtained prior to initiation of neoadjuvant chemotherapy was utilized for evaluation.

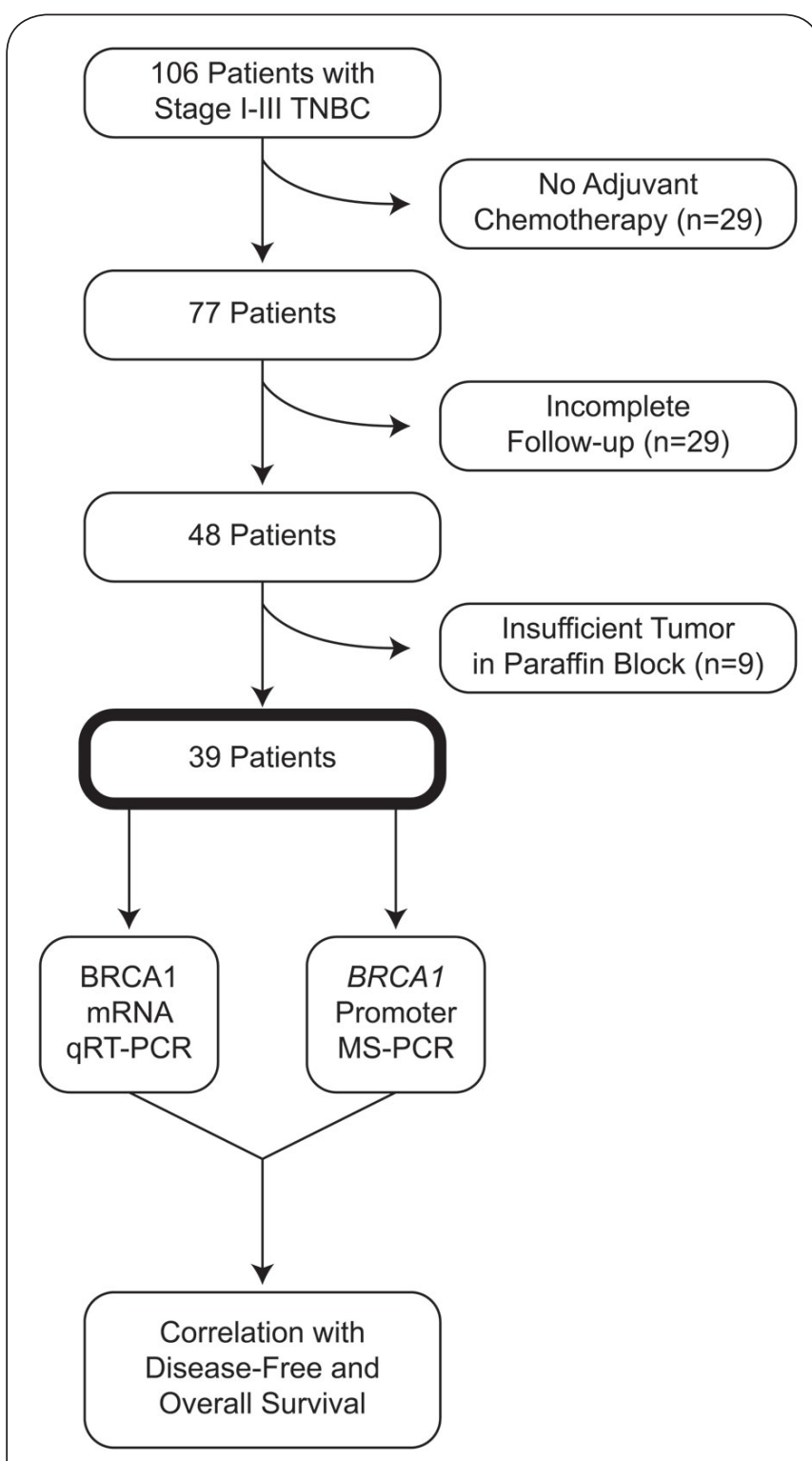

Figure 1. Identification of tumor specimens for analysis. 
Demographic and clinical information regarding patho-logical stage, breast cancer treatment, outcome etc. was collected by review of the medical charts.

\section{BRCA1 promoter methylation (BRCA1 $\mathrm{PM}$ )}

Tumor-dense areas of $20 \mu \mathrm{m}$ FFPE tissue sections were manually dissected and genomic DNA (gDNA) was isolated and bisulfite converted using the EpiTect ${ }^{\circledR}$ Plus FFPE Bisulfite Kit (Qiagen). Purified converted DNA was subjected to methylation-specific PCR (MSPCR) using the EpiTect ${ }^{\oplus}$ MSP Kit (Qiagen). The unmethylated template primers were (forward) TTGGTTTTTGTGGTAATGGAAAAGTGT and (reverse) CAAAAAATCTCAACAAACTCACACCA, resulting in an 86 base pair PCR product. The methylated template primers were (forward) TCGTGGTAACGGAAAAGCGC and (reverse) AAATCTCAACGAACTCACGCCG, resulting in a 75 base pair PCR product. These primers have been extensively characterized by previous groups (Figure 2A) [10,23]. PCR conditions were as follows: $95.0^{\circ} \mathrm{C}$ for 10 minutes, then 35 cycles of $94.0^{\circ} \mathrm{C}$ for 15 seconds, $55.0^{\circ} \mathrm{C}$ for 30 seconds, $72.0^{\circ} \mathrm{C}$ for 30 seconds, and a final extension at $72.0^{\circ} \mathrm{C}$ for 10 minutes. PCR products were electrophoresed on a $2.5 \%$ agarose gel stained with ethidium bromide and visualized on a UVP Bioimaging system. Specificity of the reactions was confirmed using the EpiTect ${ }^{\circledR}$ Control DNA set (Qiagen) with the same primers and PCR conditions. The presence of a methylated band was recorded as "positive" for BRCA1 PM (Figures 2B-2C).

BRCA1 mRNA quantitative real-time PCR (qRT-PCR) Total RNA was isolated using the RecoverAll ${ }^{\text {TM }}$ kit (Life Technologies), which includes DNAse treatment performed to remove genomic DNA. RNA was reverse transcribed to CDNA using SMARTScribe ${ }^{T M}$ reverse transcriptase (Clontech) and random nonamer primer. CDNAs were assayed in duplicate for expression of $B R C A 1$ transcript levels as well as reference transcripts using specific primer and probe sets (TaqMan ${ }^{\circledR}$ Gene Expression Assays; Life Technologies) and TaqMan ${ }^{\circledR}$ chemistry [24]. Cycle threshold $(\mathrm{Ct})$ values were calculated for each endpoint, corrected for housekeeping gene expression (cyclophillin A and hypoxanthine phosphoribosyltransferase 1) and relative gene expression was calculated using the $\Delta \Delta \mathrm{Ct}$ method. Expression is reported as multiples of the median.

\section{Analysis of TCGA dataset}

BRCA1 gene expression (Agilent platform) and DNA methylation (Human Methylation27 and Human Methylation450 arrays) data for TNBC breast cancer specimens were obtained from the TCGA database and analyzed as described previously [25]. Briefly, the z-scores for BRCA1 mRNA expression and beta values for DNA methylation (four probes spanning the promoter region of interest: cg04658354, cg08993267, cg19088651 and cg19531713) for 56 TNBC samples (for which both expression and methylation data were available at the time of analysis) were downloaded from TCGA portal

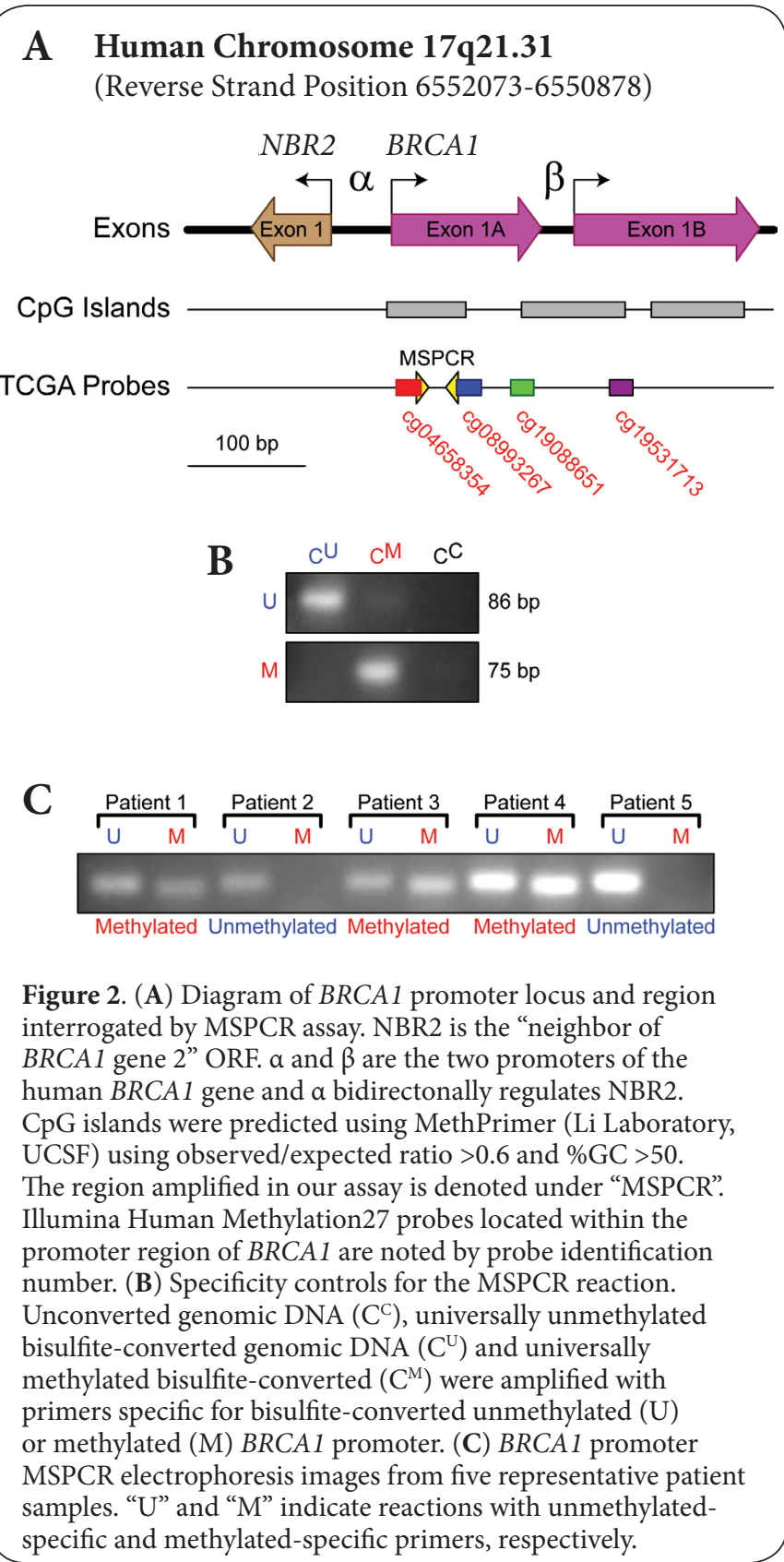

(Figure 2A) (http://tcga-data.nci.nih.gov/tcga/tcgaHome2. jsp). Correlation analysis between BRCA1 mRNA expression and $B R C A 1$ promoter DNA methylation (at each of the four $\mathrm{CpG}$ islands individually and the mean beta value of all four probes) was performed using GraphPad Prism.

\section{Statistical analysis}

Patient characteristics were compared between groups (BRCA1 PM present vs. BRCA1 PM absent) by a chi-square test or Wilcoxon's rank-sum test, as appropriate. Time to recurrence was measured from the date of diagnosis to the date of local 
or systemic recurrence or the last follow-up. Overall survival (OS) time was measured from the date of diagnosis to the date of death, or the last follow-up.

Survival outcomes were estimated according to the Kaplan-Meier method and compared between groups by the log-rank statistic. Cox proportional hazards models were fit to determine the association of BRCA1 PM with the risk of recurrence and death after adjustment for other characteristics.

\section{Results}

\section{Study population}

Under an IRB-approved protocol, 48 patients with stage I-III TNBC who had definitive surgery at our institution between 1996-2008, were treated with adjuvant/neoadjuvant chemotherapy, and for whom tumor specimens were available in our pathology archives were identified. Thirty-nine of 48 subjects with TNBC had adequate tumor specimen available for analysis. Table 1 describes the baseline demographics of the study population. All patients received systemic chemotherapy for early stage disease ( $74 \%$ received adjuvant and $26 \%$ received neoadjuvant chemotherapy). For patients who received neoadjuvant chemotherapy, the biopsy specimen

Table 1. Baseline characteristics.

\begin{tabular}{|c|c|c|c|c|}
\hline \multirow[t]{2}{*}{ Characteristics } & \multirow[t]{2}{*}{ Total } & \multicolumn{2}{|c|}{ BRCA1 methylation* } & \multirow[t]{2}{*}{ P-value } \\
\hline & & Methylated & Unmethylated & \\
\hline $\mathrm{N}$ & 39 & 11 & 26 & -- \\
\hline $\begin{array}{l}\text { Median age at } \\
\text { diagnosis (range) }\end{array}$ & $52(33-80)$ & $47(33-61)$ & $53(39-80)$ & 0.067 \\
\hline Ethnicity & & & & 0.40 \\
\hline $\begin{array}{l}\text { Caucasian } \\
\text { African American } \\
\text { Hispanics }\end{array}$ & $\begin{array}{l}29(74 \%) \\
7(18 \%) \\
3(8 \%)\end{array}$ & $\begin{array}{l}8(73 \%) \\
3(27 \%) \\
0\end{array}$ & $\begin{array}{l}19(73 \%) \\
4(15 \%) \\
3(12 \%)\end{array}$ & \\
\hline Lymph Node status & & & & 1.00 \\
\hline $\begin{array}{l}\text { Negative } \\
\text { Positive }\end{array}$ & $\begin{array}{l}20(51 \%) \\
19(49 \%)\end{array}$ & $\begin{array}{l}5(46 \%) \\
6(54 \%)\end{array}$ & $\begin{array}{l}13(50 \%) \\
13(50 \%)\end{array}$ & \\
\hline $\begin{array}{l}\text { Pathological TNM Stage } \\
\text { I } \\
\text { II } \\
\text { III }\end{array}$ & $\begin{array}{l}12(30 \%) \\
15(39 \%) \\
12(31 \%)\end{array}$ & $\begin{array}{l}2(18 \%) \\
4(36 \%) \\
5(46 \%)\end{array}$ & $\begin{array}{l}9(35 \%) \\
10(39 \%) \\
7(27 \%)\end{array}$ & 0.47 \\
\hline Lymphovascular invasion & & & & 0.72 \\
\hline $\begin{array}{l}\text { Present } \\
\text { Absent }\end{array}$ & $\begin{array}{l}18(47 \%) \\
20(53 \%) \\
\end{array}$ & $\begin{array}{l}5(46 \%) \\
6(54 \%) \\
\end{array}$ & $\begin{array}{l}14(56 \%) \\
11(44 \%) \\
\end{array}$ & \\
\hline Histology & & & & 0.30 \\
\hline $\begin{array}{l}\text { Ductal } \\
\text { Other }\end{array}$ & $\begin{array}{l}38(97 \%) \\
1(3 \%)\end{array}$ & $\begin{array}{l}10(91 \%) \\
1(9 \%)\end{array}$ & $\begin{array}{l}26(100 \%) \\
0(0 \%)\end{array}$ & \\
\hline Surgery type & & & & 1.00 \\
\hline $\begin{array}{l}\text { Breast conservation } \\
\text { Mastectomy }\end{array}$ & $\begin{array}{l}19(49 \%) \\
20(51 \%)\end{array}$ & $\begin{array}{l}5(46 \%) \\
6(54 \%)\end{array}$ & $\begin{array}{l}12(46 \%) \\
14(54 \%)\end{array}$ & \\
\hline Chemotherapy & $39(100 \%)$ & $11(100 \%)$ & $26(100 \%)$ & -- \\
\hline Adjuvant & $30(74 \%)$ & $6(54 \%)$ & $22(85 \%)$ & 0.09 \\
\hline Neoadjuvant & $9(26 \%)$ & $5(46 \%)$ & $4(15 \%)$ & -- \\
\hline Type of Chemotherapy & $100 \%$ & $100 \%$ & $100 \%$ & -- \\
\hline Anthracycline & $35(90 \%)$ & $10(91 \%)$ & $23(89 \%)$ & 1.00 \\
\hline Taxane & $27(69 \%)$ & $8(73 \%)$ & $18(69 \%)$ & 1.00 \\
\hline
\end{tabular}

${ }^{*} B R C A 1$ PM MSPCR was successful in 37/39 specimens obtained prior to initiation of neoadjuvant chemotherapy was utilized for the study. Ninety percent (35/39) received an anthracycline and $69 \%(27 / 39)$ received a taxane as part of systemic therapy. All patients received adjuvant radiotherapy based on standard clinical guidelines.

\section{$B R C A 1$ promoter methylation (BRCA1 $\mathrm{PM})$ and expre- ssion analysis}

BRCA1 PM MSPCR assay was successful in 95\% (37/39) of specimens and BRCA1 mRNA qRT-PCR was successful in $92 \%$ $(36 / 39)$ of specimens. BRCA1 PM was detected in $30 \%(11 / 37)$ of subjects. There was no statistically significant association between presence of BRCA1 PM and age, race, nodal status, lymphovascular invasion and clinical stage (Table 1). For 34 subjects with both $B R C A 1$ promoter methylation and $B R C A 1$ qRT-PCR data, the presence of BRCA1 PM was associated with lower $B R C A 1$ transcript levels suggesting epigenetic silencing of $B R C A 1$ gene (median $B R C A 1$ expression was 0.74 multiples of the median in tumors with BRCA1 PM compared to 1.14 in tumors without $B R C A 1 \mathrm{PM}, \mathrm{p}=0.038$, Figure 3 ).

\section{Analysis of TCGA dataset for BRCA1 PM and expression} We analyzed the TCGA breast cancer dataset for 56 TNBC specimens for which both expression (z-score) and methylation ( $\beta$-value) data were available. Among the four probes included in the TCGA dataset, two probes (cg04658354 and cg08993267) flank and overlap with the region queried by the MSPCR we used to interrogate BRCA1 PM in our study. The two additional probes (cg19088651 and cg19531713) lay 105 and 307 base pairs

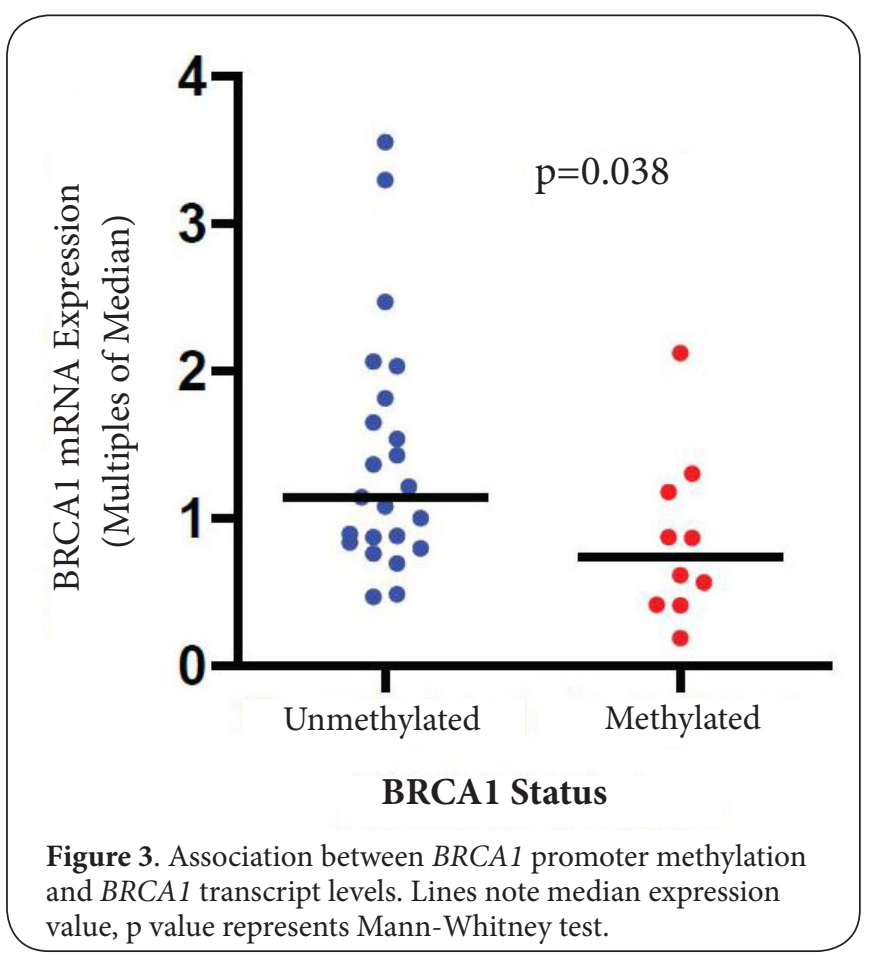


downstream from the MSPCR locus, respectively (Figure 2A). There was a significant inverse correlation between methylation and BRCA1 mRNA expression at all four probe sites individually, and when all were considered as a composite measure of methylation (Figures 4A-4B). There appeared to be a threshold at a composite $\beta$-value of approximately 0.2 (dotted line in Figure 4A), with expression of $B R C A 1$ being significantly lower $(p<0.0001)$ in the $21 \%(12 / 56)$ of tumors with a methylation value beyond this threshold (Figure 4C). Taken together, these data confirm that hypermethylation in this region is strongly associated with epigenetic silencing of the BRCA1 gene.

\section{BRCA1 PM and outcome}

At a median and mean follow-up of 64 months (range 8-148 months) and 63 months, respectively, there have been 18 $(46 \%)$ recurrences and $14(36 \%)$ deaths. Survival estimates are summarized in Table 2. Node positivity, higher stage, AfricanAmerican race and presence of BRCA1 PM were associated with worse RFS and OS (univariate analysis). Chemotherapy regimens (taxane-containing vs. non-taxane-containing regimens and anthracycline-containing vs. non-anthracyclinecontaining regimens) did not impact RFS or OS (although this analysis is limited, as only $31 \%$ of our cohort received a non-taxane regimen and $10 \%$ received a non-anthracycline regimen). Five-year RFS was $27 \%$ for patients with $B R C A 1$ PM versus $62 \%$ for patients without $B R C A 1 \mathrm{PM},(\mathrm{p}=0.041$, log rank test). Five-year OS was $36 \%$ for patients with $B R C A 1 \mathrm{PM}$ versus $77 \%$ for patients without $B R C A 1 \mathrm{PM},(\mathrm{p}=0.004$, log rank test). The Kaplan-Meier plots for RFS and OS by methylation status are shown in Figure 5. RFS and OS remained significant after excluding the four patients (three BRCA1-unmethylated, one $B R C A 1$-methylated) who did not receive an anthracycline as part of systemic therapy (data not shown).

Table 3 summarizes the results of the multivariable Cox proportional hazards models for RFS and OS. Included in the models were variables identified as significant $(p<0.05)$ by univariate analysis (i.e., African-American race, stage 3 disease, node positivity, lymphovascular invasion, methylation status and BRCA1 mRNA expression). In addition to AfricanAmerican race and node positivity, presence of $B R C A 1 \mathrm{PM}$ was associated with a worse RFS (HR: 3.5, 95\% Cl: 1.3-9.8, $p=0.016$ ) and OS (HR: 6.2, 95\% Cl: 2.0-19.4, $\mathrm{p}=0.002$ ) when compared to patients without BRCA1 PM. BRCA1 mRNA expression, stage and lymphovascular invasion were not significant predictors for RFS and OS in the multivariable model.

\section{$B R C A 1$ expression and outcome}

We also examined the impact of $B R C A 1 \mathrm{mRNA}$ expression on RFS and OS. Five-year RFS was $44 \%$ for patients with $B R C A 1$ expression in the lowest three quartiles compared to $89 \%$ for patients with $B R C A 1$ expression in the highest quartile $(p=0.034, \log$ rank test). While the same trend was maintained for OS (Five-year OS 67\% lowest three quartiles; $89 \%$ highest quartile), the trend was not statistically significant ( $p=0.099$,

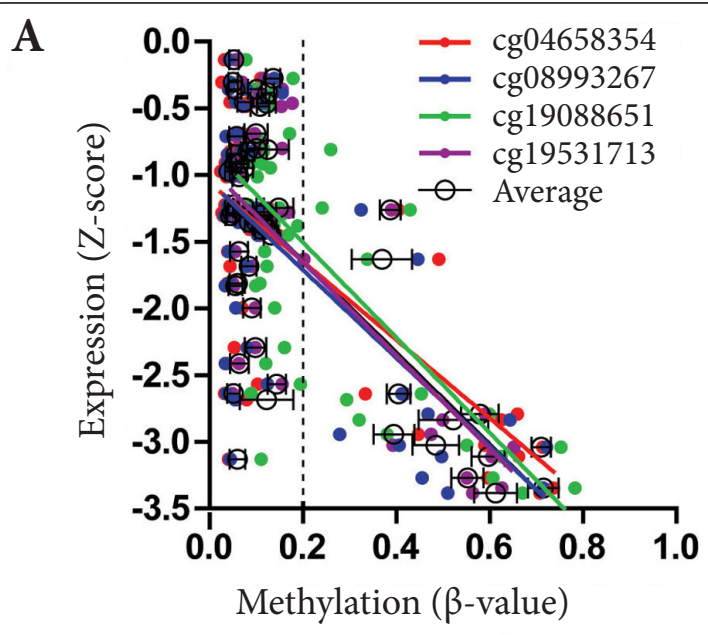

B

\begin{tabular}{|c|c|c|}
\cline { 2 - 3 } \multicolumn{1}{c|}{} & $\mathbf{r}$ & $\mathbf{p}$ \\
\hline cg04658354 & -0.48 & 0.0002 \\
\hline cg08993267 & -0.40 & 0.0024 \\
\hline cg19088651 & -0.57 & $<0.0001$ \\
\hline cg19531713 & -0.34 & 0.0108 \\
\hline Average & -0.46 & 0.0003 \\
\hline
\end{tabular}

C

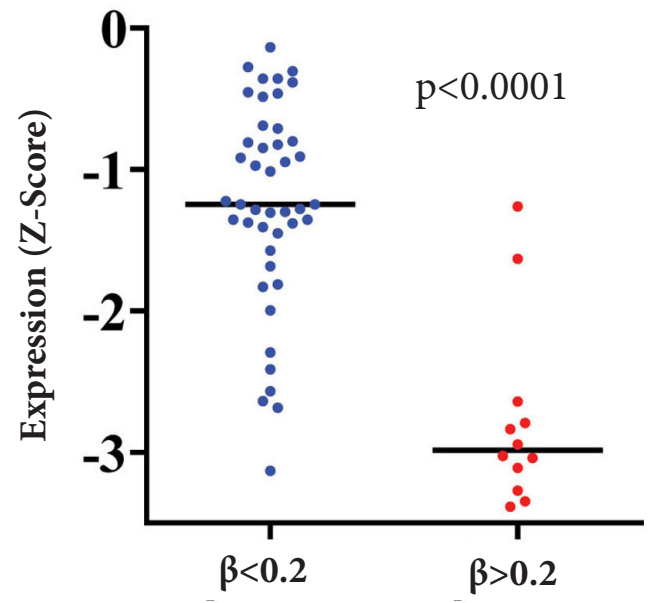

Figure 4. (A) Correlation analysis between $B R C A 1$ expression and methylation across 56 TNBC specimens (for which both expression and methylation data were available) obtained from the TCGA breast cancer database. (B) Correlation coefficients and significance of methylation and mRNA expression from TCGA dataset. (C) Association between $B R C A 1$ promoter methylation (determined by average TCGA probe $\beta$-value $>0.2$ ) and $B R C A 1 \mathrm{mRNA}$ expression. Lines note median expression value, $\mathrm{p}$ value represents Mann-Whitney test. 
Table 2. Recurrence Free Survival and Overall Survival estimates.

\begin{tabular}{|c|c|c|c|c|c|}
\hline \multicolumn{6}{|c|}{ Recurrence Free Survival } \\
\hline & $n$ at risk & $n$ events & 5-year RFS & $95 \% \mathrm{CI}$ & p value ${ }^{*}$ \\
\hline All & 39 & 18 & $52 \%$ & $(38 \%, 70 \%)$ & -- \\
\hline \multicolumn{6}{|l|}{ Race } \\
\hline AA & 7 & 6 & $14 \%$ & $(0 \%, 40 \%)$ & $0.015^{\dagger}$ \\
\hline Not AA & 32 & 12 & $62 \%$ & $(46 \%, 79 \%)$ & -- \\
\hline White & 29 & 11 & $62 \%$ & $(45 \%, 80 \%)$ & 0.051 \\
\hline Other & 3 & 1 & $67 \%$ & $(13 \%, 100 \%)$ & -- \\
\hline \multicolumn{6}{|l|}{ Age $^{*}$} \\
\hline Below median & 19 & 11 & $42 \%$ & $(20 \%, 64 \%)$ & -- \\
\hline Above median & 20 & 7 & $65 \%$ & $(44 \%, 86 \%)$ & 0.22 \\
\hline \multicolumn{6}{|c|}{ Pathological TNM Stage } \\
\hline I and II & 27 & 8 & $70 \%$ & $(53 \%, 88 \%)$ & -- \\
\hline III & 12 & 10 & $16 \%$ & $(0 \%, 38 \%)$ & $<0.001$ \\
\hline \multicolumn{6}{|c|}{ Lymphovascular invasion } \\
\hline Present & 18 & 11 & $39 \%$ & $(16 \%, 61 \%)$ & 0.050 \\
\hline Absent & 20 & 6 & $70 \%$ & $(50 \%, 90 \%)$ & -- \\
\hline \multicolumn{6}{|l|}{ Lymph Node status } \\
\hline Node Negative & 20 & 4 & $80 \%$ & $(63 \%, 97 \%)$ & -- \\
\hline Node Positive & 19 & 14 & $26 \%$ & $(7 \%, 46 \%)$ & $<0.001$ \\
\hline \multicolumn{6}{|l|}{ BRCA1 PM Status } \\
\hline Not methylated & 26 & 10 & $61 \%$ & $(43 \%, 80 \%)$ & -- \\
\hline Methylated & 11 & 8 & $27 \%$ & $(1 \%, 54 \%)$ & 0.041 \\
\hline \multicolumn{6}{|l|}{ BRCA1 expression $^{\S}$} \\
\hline Lower three quartiles & 27 & 15 & $44 \%$ & $(27 \%, 62 \%)$ & -- \\
\hline Highest Quartile & 9 & 1 & $89 \%$ & $(72 \%, 100 \%)$ & 0.34 \\
\hline \multicolumn{6}{|c|}{ Overall Survival } \\
\hline & $n$ at risk & $n$ events & 5-year OS & $95 \% \mathrm{CI}$ & p value ${ }^{\star}$ \\
\hline All & 39 & 14 & $69 \%$ & $(55 \%, 84 \%)$ & -- \\
\hline \multicolumn{6}{|l|}{ Race } \\
\hline AA & 7 & 5 & $27 \%$ & $(0 \%, 62 \%)$ & $0.011^{\dagger}$ \\
\hline Not AA & 32 & 9 & $78 \%$ & $(64 \%, 92 \%)$ & -- \\
\hline White & 29 & 8 & $79 \%$ & $(65 \%, 94 \%)$ & 0.036 \\
\hline Other & 3 & 1 & $67 \%$ & $(13 \%, 100 \%)$ & -- \\
\hline \multicolumn{6}{|l|}{ Age $^{*}$} \\
\hline Below median & 19 & 9 & $57 \%$ & $(35 \%, 80 \%)$ & -- \\
\hline Above median & 20 & 5 & $80 \%$ & $(63 \%, 97 \%)$ & 0.19 \\
\hline \multicolumn{6}{|l|}{ Lymph Node status } \\
\hline Negative & 20 & 2 & $90 \%$ & $(76 \%, 100 \%)$ & -- \\
\hline Positive & 19 & 12 & $47 \%$ & $(25 \%, 70 \%)$ & $<0.001$ \\
\hline \multicolumn{6}{|c|}{ Pathological TNM Stage } \\
\hline I and II & 27 & 5 & $90 \%$ & $(77 \%, 100 \%)$ & -- \\
\hline III & 12 & 9 & $25 \%$ & $(1 \%, 50 \%)$ & $<0.001$ \\
\hline \multicolumn{6}{|c|}{ Lymphovascular invasion } \\
\hline Present & 18 & 9 & $61 \%$ & $(39 \%, 84 \%)$ & 0.12 \\
\hline Absent & 20 & 5 & $75 \%$ & $(56 \%, 94 \%)$ & -- \\
\hline \multicolumn{6}{|l|}{ BRCA1 PM Status } \\
\hline Not methylated & 26 & 6 & $81 \%$ & $(66 \%, 96 \%)$ & -- \\
\hline Methylated & 11 & 8 & $36 \%$ & $(8 \%, 65 \%)$ & 0.004 \\
\hline \multicolumn{6}{|l|}{ BRCA1 expression $^{\S}$} \\
\hline Lower three quartiles & 27 & 11 & $67 \%$ & $(49 \%, 84 \%)$ & -- \\
\hline Highest Quartile & 9 & 1 & $89 \%$ & $(72 \%, 100 \%)$ & 0.99 \\
\hline
\end{tabular}

${ }^{*}$ Log rank test; ${ }^{\dagger} \mathrm{AA}$ compared to non AA; ${ }^{\ddagger}$ Median age 52 years;

${ }^{\circledR}$ BRCA1 PM MSPCR assay was successful in 37/39 subjects; ${ }^{\circ}$ BRCA1 mRNA qRT-PCR was successful in $36 / 39$ subjects 


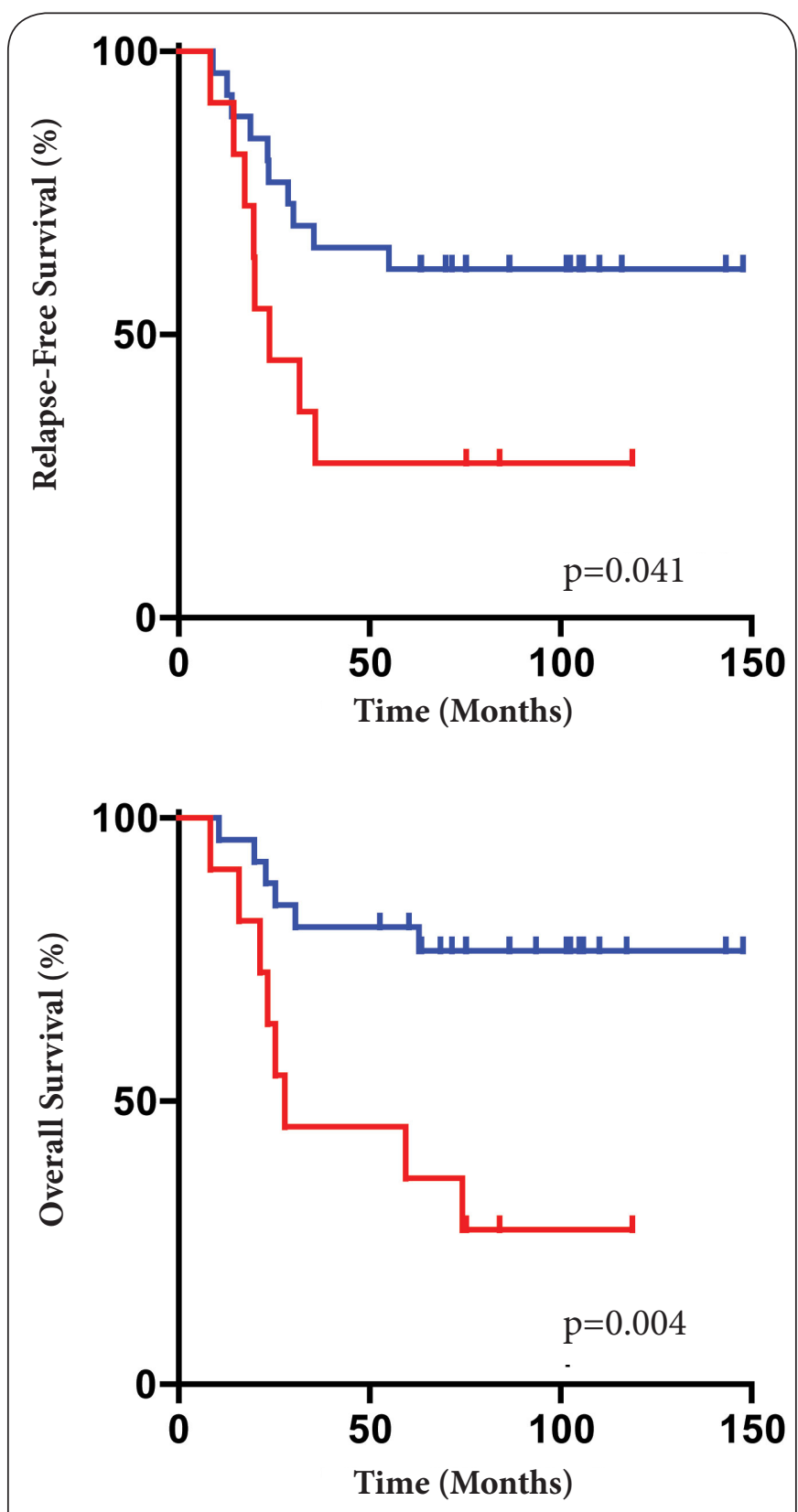

\section{BRCA1 Unmethylated \\ — BRCA1 Methylated}

Figure 5. Kaplan-Meier survival plots for recurrence-free survival (RFS) and overall survival (OS) by methylation status. Tick marks denote time of censoring.

log rank test). The Kaplan-Meier plot for RFS by BRCA1 mRNA quartiles is shown in Figure 6. BRCA1 mRNA expression was not a significant predictor of RFS and OS in the multivariable model. Thus, BRCA1 PM was a more robust prognostic indicator compared to BRCA1 expression in our data set.
Table 3. Multivariable Cox proportional hazards models*.

\begin{tabular}{|c|c|c|c|}
\hline \multicolumn{4}{|c|}{ RFS estimates } \\
\hline & HR & $95 \%$ CI & $\mathbf{P}$ \\
\hline \multicolumn{4}{|c|}{ BRCA1 PM Status } \\
\hline Not methylated & 1.0 & $(1.3,9.8)$ & 0.016 \\
\hline Methylated & 3.5 & -- & -- \\
\hline \multicolumn{4}{|l|}{ Race } \\
\hline Non AA & 1.0 & $(1.6,12.9)$ & 0.006 \\
\hline AA & 4.5 & -- & -- \\
\hline \multicolumn{4}{|l|}{ Nodal Status } \\
\hline Negative & 1.0 & $(2.7,31.8)$ & $<0.001$ \\
\hline Positive & 9.3 & -- & -- \\
\hline \multicolumn{4}{|c|}{ OS estimates } \\
\hline & HR & 95\% CI & $\mathbf{P}$ \\
\hline \multicolumn{4}{|c|}{ BRCA1 PM Status } \\
\hline Not methylated & 1.0 & $(2.0,19.4)$ & 0.002 \\
\hline Methylated & 6.2 & -- & -- \\
\hline \multicolumn{4}{|l|}{ Race } \\
\hline Non AA & 1.0 & $(2.2,31.1)$ & 0.002 \\
\hline $\mathrm{AA}$ & 8.3 & -- & -- \\
\hline \multicolumn{4}{|l|}{ Nodal Status } \\
\hline Negative & 1.0 & $93.2-86.10$ & 0.001 \\
\hline Positive & 16.7 & -- & -- \\
\hline
\end{tabular}

*Variables included: race, pathological stage, node positivity, lymphovascular invasion $B R C A 1$ expression and methylation status. Stage, lymphovascular invasion and $B R C A 1$ expression were not significant in the multivariable model.

At present, the TCGA breast cancer dataset has a short median follow-up (17 months) and a small number of overall survival events, limiting the utility of this dataset in performing survival analyses [9].

\section{Discussion}

It is well established that patients with TNBC have a worse outcome compared to patients with other breast cancer subtypes $[1,5,6,26]$. One of the challenges in developing newer agents for treatment of TNBC has been lack of predictors of resistance to standard chemotherapy, as routine clinical and pathological variables do not clearly identify TNBC patients who are likely to develop recurrence with standard therapy. In this unselected cohort of TNBC patients who were treated with modern chemotherapy regimens, we have demonstrated that BRCA1 PM can be used as a marker to identify patients who are destined to have a poor outcome. BRCA1 PM was detected in $30 \%$ of subjects with TNBC, was associated with lower $B R C A 1$ transcript levels (suggesting epigenetic silencing of $B R C A 1$ gene) and was an independent predictor of poor outcome. Low BRCA1 expression, although associated with inferior RFS in univariate analysis, was not an independent predictor in the multivariable model. We believe that the small size limited our ability to adequately evaluate a continuous marker such as BRCA1 expression. 

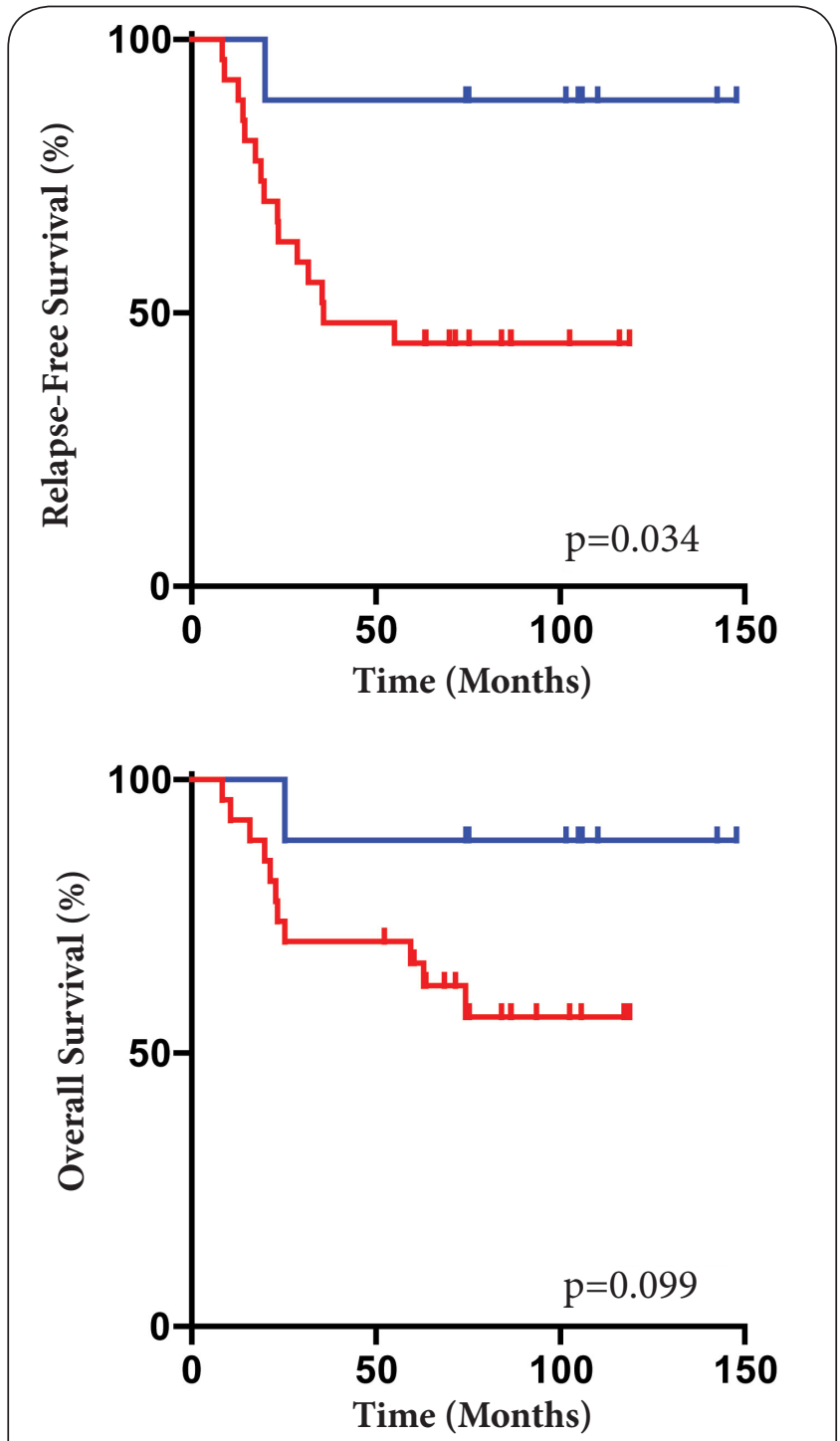

$\perp$ Quartile 4

1 Quartiles 1-3

Figure 6. Kaplan-Meier survival plots for recurrence-free survival (RFS) and overall survival (OS) by BRCA1 mRNA quartiles. Tick marks denote time of censoring.

Our study adds to the existing data on the prognostic impact of BRCA1 PM and expression in patients with TNBC. Although small, this is the first study to evaluate the prognostic impact of BRCA1 PM in context of modern chemotherapy ( $70 \%$ of our cohort received both Anthracycline and taxane). In a recent publication, Xu et al., evaluated the impact of $B R C A 1$ PM on outcome in Chinese breast cancer patients [20]. BRCA1 PM was detected in $30 \%$ of TNBC patients, and in a subgroup of chemotherapy treated patients BRCA1 PM was associated with poor outcome in non-TNBC patients and better outcome in TNBC patients. These findings are in contrast to our study. Methylation of $B R C A 1$ promoter leads to $B R C A 1$ gene silencing and there is no preclinical data to suggest that the biological therapeutic sequelae of $B R C A 1$ silencing depends on the subtype of breast cancer. Thus, the reasons underlying the differential impact of $B R C A 1$ PM on chemotherapy response in triple negative and non-triple negative breast cancer in Xu et al., study are not clear. Furthermore, BRCA1 mRNA expression analysis to confirm gene silencing is not reported Xu et al., cohort. Differences in chemotherapy regimens between the two cohorts can also explain the disparity between the findings. The majority of patients in the Xu et al., study were treated in 1990s and received non-anthracycline/taxane based chemotherapy, whereas most of our patients received anthracycline/taxane based therapy.

Although important, our study has several limitations. This is a small, retrospective study and results are subject to bias due to the retrospective nature and small sample size [27]. Our findings need to be confirmed in other larger independent cohorts. We do not have germline BRCA 1 information on all patients. Only $33 \%$ of the cohort underwent commercial $B R C A$ germline testing, and none were found to carry a $B R C A$ mutation. It is possible that the presence of unidentified $B R C A$ germline mutations in untested patients impacted our results. It has previously been shown that the presence of a $B R C A 1$ germline mutation and BRCA1 PM typically do not co-exist in the same tumor (i.e., BRCA1 PM is not observed in $B R C A 1$ germline mutation associated tumors) $[\mathbf{9 , 1 1 , 2 8 , 2 9 ]}$. Thus, co-existence of germline BRCA mutations are unlikely to contribute to the poorer outcome observed in our patients with methylated tumors. In the majority of prior studies, the outcomes of BRCA mutation-associated breast cancers are reported to be similar to patients with sporadic breast cancer [30-34]. Thus, it is also unlikely that the superior outcome observed in patients with unmethylated tumors in our study was driven by presence of $B R C A$ germline mutations in this group.

While the present study does not mechanistically explain the poorer outcome in BRCA1-methylated tumors, several potential explanations can be evoked. We were the first to show that decreased expression of BRCA 1 occurs in sporadic breast cancer at the transition from ductal carcinoma in situ to invasive ductal carcinoma, and that experimental knockdown of BRCA1 expression leads to accelerated growth of both normal and malignant mammary epithelial cells [35]. Several recent studies have suggested that loss of BRCA1 expression or function leads to expansion of cell populations with stem/ progenitor-like properties which classically are resistant to chemo-radiotherapy $[36,37]$. Lastly, and by direct extension, it is now appreciated that loss of $B R C A 1$, and indeed the acquisition of a stem/progenitor-like phenotype in general, is associated with the migratory and invasive characteristics of the epithelial-to-mesenchymal transition (EMT) $[38,39]$. Thus, epigenetic inactivation of $B R C A 1$ in sporadic TNBC may 
manifest an intrinsically more aggressive and invasive tumor phenotype through multiple mechanisms, including increased growth, expansion of stem/progenitor-cells, activation of proinvasive gene expression programs, and reduced therapeutic sensitivity to standard chemotherapy.

It is also possible that anthracycline- and taxane-based chemotherapy are not the ideal drugs to therapeutically capitalize on BRCA1 insufficiency brought about by epigenetic $B R C A 1$ silencing. Though anthracycline agents induce doublestrand breaks, repair of these lesions appears to require nonhomologous end joining, an error-prone double strand break repair pathway that does not require $B R C A 1$, and preclinical data suggests that anthracyclines do not exhibit selective toxicity in BRCA1-deficient cells [40-42]. Conversely, repair of platinum-induced interstrand crosslinks invokes BRCA1mediated homologous recombination, and there is abundant clinical and in vitro evidence that BRCA1-deficient cells are hypersensitive to platinum agents [41-44]. Taxanes are an integral part of chemotherapy regimens for breast cancer treatment and appear to contribute particularly among patients with early stage TNBC $[45,46]$. However, the relative efficacy of taxanes in TNBC may be impacted by BRCA1 functional state. In response to the abnormal mitosis induced by taxanes, BRCA1 induces the mitotic spindle checkpoint and triggers apoptosis [47]. In the absence of functional $B R C A 1$, this checkpoint is not activated and cells proceed through mitosis. Several in vitro studies suggest that $B R C A 1$-deficient cells are resistant to microtubule poisons $[47,48]$. Supporting these pre-clinical findings, a recent retrospective analysis demonstrated that BRCA1 mutation-associated advanced TNBCs are less sensitive to single-agent taxanes than sporadic TNBCs $[49,50]$. These data imply that anthracycline/taxane combination therapy may not be optimal for patients with $B R C A 1$-deficient tumors. We speculate that the poorer outcome we observed in BRCA1-methylated tumors resulted from the aggressive biological features imbued by $B R C A 1$ deficiency in the context of chemotherapy that does not exploit the homologous recombination defect present in BRCA1-deficient cells.

While TNBC patients with BRCA1-methylated tumors may be destined to have poor outcome with standard anthracycline/taxane-based chemotherapy, genetic or epigenetic loss of BRCA1 may be an Achilles' heel that can be harnessed for therapeutic advantage. It is now appreciated in the ovarian cancer literature that upon treatment with standard platinum-based chemotherapy, BRCA1- and $B R C A 2$-associated malignancies have an improved prognosis compared to sporadic epithelial ovarian cancers [44]. Thus, use of platinum salts may be a more rational treatment approach in breast cancers with either genetic or epigenetic inactivation $B R C A 1$. Indeed, platinum compounds are more effective than anthracyclines in treating tumors arising in a Brca 1/p53 mouse model of spontaneous breast cancer $[41,51]$. Furthermore, recent in vitro and animal data suggests that epigenetic inactivation of $B R C A 1$ leads to the same degree of sensitivity to platinum agents as observed in presence of $B R C A 1$ mutations [52]. In recent years, poly(ADP-ribose) polymerase (PARP) inhibitors have been enthusiastically evaluated for treatment of $B R C A$ mutation-associated and sporadic TNBCs. Although clinical trials of PARP inhibitors have demonstrated encouraging activity in BRCA mutationassociated breast cancers, to date PARP inhibitors have failed to demonstrate significant activity in unselected patients with sporadic TNBC [51]. Thus, there is a need to define markers that can identify sporadic TNBC tumors which are likely to benefit from this novel class of drugs. It might be possible to extend the observation of PARP inhibitor sensitivity of $B R C A 1 / B R C A 2$ mutation-associated tumors to sporadic BRCA1hypermethylated tumors. Indeed, in vitro data suggests that $B R C A 1$ hypermethylation confers the same degree of sensitivity to PARP inhibitors as does BRCA1 mutation [14].

\section{Conclusion}

Our study shows that $B R C A 1$ PM occurs frequently in TNBC and that epigenetic $B R C A 1$ silencing is associated with poor outcome in presence of modern anthracycline/taxanebased chemotherapeutic regimens. Whether BRCA1 PM is indeed a robust prognostic biomarker in this regard needs to be confirmed in larger cohorts from prospective clinical trials. If validated in larger cohorts, BRCA1 PM can serve as a clinically useful biomarker to identify TNBC patients who are likely to experience suboptimal outcomes with standard chemotherapy. BRCA1 PM may potentially also be used as a patient selection criterion for to identify patients who may benefit from therapeutic approaches which target BRCA1 deficiency, including platinum compounds and/or PARP inhibitors.

\section{Competing interests}

The authors declare that they have no competing interests.

\section{Authors' contributions}

\begin{tabular}{|l|c|c|c|c|c|c|c|c|c|}
\hline Authors' contributions & PS & SRS & BFK & GS & BKP & TAP & OWT & AKG & RAJ \\
\hline $\begin{array}{l}\text { Research concept and } \\
\text { design }\end{array}$ & $\checkmark$ & $\checkmark$ & -- & -- & -- & -- & -- & -- & $\checkmark$ \\
\hline $\begin{array}{l}\text { Collection and/or } \\
\text { assembly of data }\end{array}$ & $\checkmark$ & $\checkmark$ & -- & $\checkmark$ & $\checkmark$ & $\checkmark$ & $\checkmark$ & $\checkmark$ & -- \\
\hline $\begin{array}{l}\text { Data analysis and } \\
\text { interpretation }\end{array}$ & $\checkmark$ & $\checkmark$ & -- & -- & -- & -- & -- & -- & -- \\
\hline Writing the article & $\checkmark$ & $\checkmark$ & -- & -- & -- & -- & -- & -- & -- \\
\hline $\begin{array}{l}\text { Critical revision of the } \\
\text { article }\end{array}$ & $\checkmark$ & $\checkmark$ & -- & -- & -- & -- & -- & $\checkmark$ & $\checkmark$ \\
\hline Final approval of article & $\checkmark$ & $\checkmark$ & $\checkmark$ & $\checkmark$ & $\checkmark$ & $\checkmark$ & $\checkmark$ & $\checkmark$ & $\checkmark$ \\
\hline Statistical analysis & $\checkmark$ & $\checkmark$ & $\checkmark$ & -- & -- & -- & -- & -- & - \\
\hline
\end{tabular}

Acknowledgement and funding This work was funded by SEED grant from the Department of Internal Medicine Office of Scholarly, Academic \& Research Mentoring (OSARM), University of Kansas Medical Center and an NIH Clinical and Translational Science 
Award grant (UL1 TR000001, formerly UL1RR033179), awarded to the University of Kansas Medical Center.

\section{Publication history}

EIC: G. J. Peters, VU University Medical Center, Netherlands. Received: 30-Jan-2014 Revised: 21-Feb-2014

Accepted: 06-Mar-2014 Published: 19-Mar-2014

\section{References}

1. Osborne C, Kannan L, Xie XJ, Ashfaq R, Bian A and Baylor TD. Neoadjuvant chemotherapy for basal-like breast cancer cohort: clinical and pathological outcomes. Breast Cancer Res. and Treat. 2006; 100:S53-S53.

2. Liedtke C, Mazouni C, Hess KR, Andre F, Tordai A, Mejia JA, Symmans WF, Gonzalez-Angulo AM, Hennessy B, Green M, Cristofanilli M, Hortobagyi GN and Pusztai L. Response to neoadjuvant therapy and long-term survival in patients with triple-negative breast cancer. J Clin Oncol. 2008; 26:1275-81. | Article | PubMed

3. Dent R, Trudeau M, Pritchard KI, Hanna WM, Kahn HK, Sawka CA, Lickley LA, Rawlinson E, Sun P and Narod SA. Triple-negative breast cancer: clinical features and patterns of recurrence. Clin Cancer Res. 2007; 13:4429-34. | Article | PubMed

4. Nielsen TO, Hsu FD, Jensen K, Cheang M, Karaca G, Hu Z, HernandezBoussard T, Livasy C, Cowan D, Dressler L, Akslen LA, Ragaz J, Gown AM, Gilks CB, van de Rijn M and Perou CM. Immunohistochemical and clinical characterization of the basal-like subtype of invasive breast carcinoma. Clin Cancer Res. 2004; 10:5367-74. | Article | PubMed

5. Haffty BG, Yang $Q$, Reiss M, Kearney T, Higgins SA, Weidhaas J, Harris L, Hait $W$ and Toppmeyer D. Locoregional relapse and distant metastasis in conservatively managed triple negative early-stage breast cancer. J Clin Oncol. 2006; 24:5652-7. | Article | PubMed

6. Tan DS, Marchio C, Jones RL, Savage K, Smith IE, Dowsett M and Reis-Filho JS. Triple negative breast cancer: molecular profiling and prognostic impact in adjuvant anthracycline-treated patients. Breast Cancer Res Treat. 2008; 111:27-44. | Article | PubMed

7. Gonzalez-Angulo AM, Timms KM, Liu S, Chen H, Litton JK, Potter J, Lanchbury JS, Stemke-Hale K, Hennessy BT, Arun BK, Hortobagyi GN, Do KA, Mills GB and Meric-Bernstam F. Incidence and outcome of BRCA mutations in unselected patients with triple receptor-negative breast cancer. Clin Cancer Res. 2011; 17:1082-9. | Article | PubMed Abstract | PubMed Full Text

8. Sharma P, Khan Q, Kimler B, Klemp J, Connor C, McGinness M, Mammen J, Tawfik O, Fan F and Fabian C. Abstract P1-11-07: Results of a Phase II Study of Neoadjuvant Platinum/Taxane Based Chemotherapy and Erlotinib for Triple Negative Breast Cancer. Cancer Res. 2010; 70:P1-1107. | Article

9. Comprehensive molecular portraits of human breast tumours. Nature. 2012; 490:61-70. | Article | PubMed Abstract | PubMed Full Text

10. Esteller M, Silva JM, Dominguez G, Bonilla F, Matias-Guiu X, Lerma E, Bussaglia E, Prat J, Harkes IC, Repasky EA, Gabrielson E, Schutte M, Baylin SB and Herman JG. Promoter hypermethylation and BRCA1 inactivation in sporadic breast and ovarian tumors. J Natl Cancer Inst. 2000; 92:5649. | Article | PubMed

11. Wei M, Grushko TA, Dignam J, Hagos F, Nanda R, Sveen L, Xu J, Fackenthal J, Tretiakova M, Das S and Olopade OI. BRCA1 promoter methylation in sporadic breast cancer is associated with reduced BRCA1 copy number and chromosome 17 aneusomy. Cancer Res. 2005; 65:10692-9. | Article I PubMed

12. Hedenfalk I, Duggan $D$, Chen $Y$, Radmacher $M$, Bittner $M$, Simon $R$, Meltzer P, Gusterson B, Esteller M, Kallioniemi OP, Wilfond B, Borg A, Trent J, Raffeld M, Yakhini Z, Ben-Dor A, Dougherty E, Kononen J, Bubendorf L, Fehrle W, Pittaluga S, Gruvberger S, Loman N, Johannsson $\mathrm{O}$, Olsson $\mathrm{H}$ and Sauter $\mathrm{G}$. Gene-expression profiles in hereditary breast cancer. N Eng/ J Med. 2001; 344:539-48. | Article | PubMed

13. Grushko TA, Nwachukwu C, Charoenthammaraksa S, Huo D, Khramtsov A,
Mashek H, Zhang C, Xu J, Perou CM and Olopade OI. Evaluation of BRCA1 inactivation by promoter methylation as a marker of triple-negative and basal-like breast cancers. J. Clin. Oncol. 2010; 28:S10510. | Article

14. Veeck J, Ropero S, Setien F, Gonzalez-Suarez E, Osorio A, Benitez J, Herman JG and Esteller M. BRCA1 CpG island hypermethylation predicts sensitivity to poly(adenosine diphosphate)-ribose polymerase inhibitors. J Clin Oncol. 2010; 28:e563-4. | Article | PubMed

15. Xu X, Gammon MD, Zhang Y, Cho YH, Wetmur JG, Bradshaw PT, Garbowski G, Hibshoosh H, Teitelbaum SL, Neugut Al, Santella RM and Chen J. Gene promoter methylation is associated with increased mortality among women with breast cancer. Breast Cancer Res Treat. 2010; 121:685-92. | Article | PubMed Abstract | PubMed Full Text

16. Sgagias MK, Wagner KU, Hamik B, Stoeger S, Spieker R, Huber LJ, Chodosh LA and Cowan KH. Brca1-deficient murine mammary epithelial cells have increased sensitivity to CDDP and MMS. Cell Cycle. 2004; 3:1451-6. | Article | PubMed

17. Santarosa M, Del Col L, Tonin E, Caragnano A, Viel A and Maestro R. Premature senescence is a major response to DNA cross-linking agents in BRCA1-defective cells: implication for tailored treatments of BRCA1 mutation carriers. Mol Cancer Ther. 2009; 8:844-54. | Article | PubMed

18. Silver DP, Richardson AL, Eklund AC, Wang ZC, Szallasi Z, Li Q, Juul N, Leong CO, Calogrias D, Buraimoh A, Fatima A, Gelman RS, Ryan PD, Tung NM, De Nicolo A, Ganesan S, Miron A, Colin C, Sgroi DC, Ellisen LW, Winer EP and Garber JE. Efficacy of neoadjuvant Cisplatin in triple-negative breast cancer. J Clin Oncol. 2010; 28:1145-53. | Article | PubMed Abstract | PubMed Full Text

19. Sharma G, Mirza S, Parshad R, Srivastava A, Gupta SD, Pandya P and Ralhan R. Clinical significance of promoter hypermethylation of DNA repair genes in tumor and serum DNA in invasive ductal breast carcinoma patients. Life Sci. 2010; 87:83-91. | Article | PubMed

20. Xu Y, Diao L, Chen Y, Liu Y, Wang C, Ouyang T, Li J, Wang T, Fan Z, Fan T, Lin $B$, Deng D, Narod SA and Xie Y. Promoter methylation of BRCA1 in triplenegative breast cancer predicts sensitivity to adjuvant chemotherapy. Ann Oncol. 2013; 24:1498-505. | Article | PubMed

21. Lips EH, Mulder L, Hannemann J, Laddach N, Vrancken Peeters MT, van de Vijver MJ, Wesseling J, Nederlof PM and Rodenhuis S. Indicators of homologous recombination deficiency in breast cancer and association with response to neoadjuvant chemotherapy. Ann Oncol. 2011; 22:8706. | Article | PubMed

22. Ignatov T, Poehlmann A, Ignatov A, Schinlauer A, Costa SD, Roessner A, Kalinski T and Bischoff J. BRCA1 promoter methylation is a marker of better response to anthracycline-based therapy in sporadic TNBC. Breast Cancer Res Treat. 2013; 141:205-12. | Article | PubMed

23. Matros E, Wang ZC, Lodeiro G, Miron A, Iglehart JD and Richardson AL. BRCA1 promoter methylation in sporadic breast tumors: relationship to gene expression profiles. Breast Cancer Res Treat. 2005; 91:179-86. | Article | PubMed

24. Petroff BK, Phillips TA, Kimler BF and Fabian CJ. Detection of biomarker gene expression by real-time polymerase chain reaction using amplified ribonucleic acids from formalin-fixed random periareolar fine needle aspirates of human breast tissue. Anal Quant Cytol Histol. 2006; 28:297302. | Article | PubMed

25. Sethi G, Pathak HB, Zhang H, Zhou Y, Einarson MB, Vathipadiekal V, Gunewardena S, Birrer MJ and Godwin AK. An RNA interference lethality screen of the human druggable genome to identify molecular vulnerabilities in epithelial ovarian cancer. PLoS One. 2012; 7:e47086. Article | PubMed Abstract | PubMed Full Text

26. Carey LA, Dees EC, Sawyer L, Gatti L, Moore DT, Collichio F, Ollila DW, Sartor $\mathrm{Cl}$, Graham ML and Perou CM. The triple negative paradox: primary tumor chemosensitivity of breast cancer subtypes. Clin Cancer Res. 2007; 13:2329-34. | Article | PubMed

27. Kim SY. Effects of sample size on robustness and prediction accuracy of a prognostic gene signature. BMC Bioinformatics. 2009; 10:147. | Article | PubMed Abstract | PubMed Full Text

28. Sharma P, Stecklein S, Kimler B, Klemp J, Khan Q, Fabian C, Tawfik O, Connor C, McGinness M, Mammen J and Jensen R. Abstract PD0902: BRCA1 insufficiency is predictive of superior survival in patients 
with triple negative breast cancer treated with platinum based chemotherapy. Cancer Res. 2012; 72:139s-140s.

29. Esteller M, Fraga MF, Guo M, Garcia-Foncillas J, Hedenfalk I, Godwin AK, Trojan J, Vaurs-Barriere C, Bignon YJ, Ramus S, Benitez J, Caldes T, Akiyama Y, Yuasa Y, Launonen V, Canal MJ, Rodriguez R, Capella G, Peinado MA, Borg A, Aaltonen LA, Ponder BA, Baylin SB and Herman JG. DNA methylation patterns in hereditary human cancers mimic sporadic tumorigenesis. Hum Mol Genet. 2001; 10:3001-7. | Article I PubMed

30. Bordeleau L, Panchal S and Goodwin P. Prognosis of BRCA-associated breast cancer: a summary of evidence. Breast Cancer Res Treat. 2010; 119:13-24. | Article | PubMed

31. Brekelmans $C T$, Seynaeve C, Menke-Pluymers M, Bruggenwirth $H T$, Tilanus-Linthorst MM, Bartels CC, Kriege M, van Geel AN, Crepin CM, Blom JC, Meijers-Heijboer $\mathrm{H}$ and Klijn JG. Survival and prognostic factors in BRCA1-associated breast cancer. Ann Oncol. 2006; 17:391-400. | Article | PubMed

32. Brekelmans $C T$, Tilanus-Linthorst MM, Seynaeve C, vd Ouweland A, Menke-Pluymers MB, Bartels CC, Kriege M, van Geel AN, Burger CW, Eggermont AM, Meijers-Heijboer $\mathrm{H}$ and Klijn JG. Tumour characteristics, survival and prognostic factors of hereditary breast cancer from BRCA2, BRCA1- and non-BRCA1/2 families as compared to sporadic breast cancer cases. Eur J Cancer. 2007; 43:867-76. | Article | PubMed

33. Bonadona V, Dussart-Moser S, Voirin N, Sinilnikova OM, Mignotte $H$, Mathevet P, Bremond A, Treilleux I, Martin A, Romestaing P, Raudrant $D$, Rudigoz RC, Lenoir GM and Lasset C. Prognosis of early-onset breast cancer based on BRCA1/2 mutation status in a French population-based cohort and review. Breast Cancer Res Treat. 2007; 101:233-45. | Article | PubMed

34. Robson ME, Chappuis PO, Satagopan J, Wong N, Boyd J, Goffin JR, Hudis C, Roberge D, Norton L, Begin LR, Offit K and Foulkes WD. A combined analysis of outcome following breast cancer: differences in survival based on BRCA1/BRCA2 mutation status and administration of adjuvant treatment. Breast Cancer Res. 2004; 6:R8-R17. | Article | PubMed Abstract | PubMed Full Text

35. Thompson ME, Jensen RA, Obermiller PS, Page DL and Holt JT. Decreased expression of BRCA1 accelerates growth and is often present during sporadic breast cancer progression. Nat Genet. 1995; 9:444-50. | Article | PubMed

36. Liu S, Ginestier C, Charafe-Jauffret E, Foco H, Kleer CG, Merajver SD, Dontu $\mathrm{G}$ and Wicha MS. BRCA1 regulates human mammary stem/ progenitor cell fate. Proc Natl Acad Sci U S A. 2008; 105:1680-5. | Article | PubMed Abstract | PubMed Full Text

37. Lim E, Vaillant F, Wu D, Forrest NC, Pal B, Hart AH, Asselin-Labat ML, Gyorki DE, Ward T, Partanen A, Feleppa F, Huschtscha LI, Thorne HJ, Fox SB, Yan M, French JD, Brown MA, Smyth GK, Visvader JE and Lindeman GJ. Aberrant luminal progenitors as the candidate target population for basal tumor development in BRCA1 mutation carriers. Nat Med. 2009; 15:907-13. | Article | PubMed

38. Mani SA, Guo W, Liao MJ, Eaton EN, Ayyanan A, Zhou AY, Brooks M, Reinhard F, Zhang CC, Shipitsin M, Campbell LL, Polyak K, Brisken C, Yang J and Weinberg RA. The epithelial-mesenchymal transition generates cells with properties of stem cells. Cell. 2008; 133:704-15. | Article | PubMed Abstract | PubMed Full Text

39. Coene ED, Gadelha C, White N, Malhas A, Thomas B, Shaw M and Vaux DJ. A novel role for BRCA1 in regulating breast cancer cell spreading and motility. J Cell Biol. 2011; 192:497-512. | Article | PubMed Abstract | PubMed Full Text

40. Schonn I, Hennesen J and Dartsch DC. Ku70 and Rad51 vary in their importance for the repair of doxorubicin- versus etoposide-induced DNA damage. Apoptosis. 2011; 16:359-69. | Article | PubMed

41. Rottenberg $S$, Nygren AO, Pajic M, van Leeuwen FW, van der Heijden I, van de Wetering K, Liu X, de Visser KE, Gilhuijs KG, van Tellingen O, Schouten JP, Jonkers J and Borst P. Selective induction of chemotherapy resistance of mammary tumors in a conditional mouse model for hereditary breast cancer. Proc Natl Acad Sci U S A. 2007; 104:12117-22. | Article | PubMed Abstract | PubMed Full Text

42. Tassone P, Tagliaferri P, Perricelli A, Blotta S, Quaresima B, Martelli
ML, Goel A, Barbieri V, Costanzo F, Boland CR and Venuta S. BRCA1 expression modulates chemosensitivity of BRCA1-defective HCC1937 human breast cancer cells. Br J Cancer. 2003; 88:1285-91. | Article | PubMed Abstract | PubMed Full Text

43. Husain A, He G, Venkatraman ES and Spriggs DR. BRCA1 upregulation is associated with repair-mediated resistance to cisdiamminedichloroplatinum(II). Cancer Res. 1998; 58:1120-3. | PubMed

44. Bolton KL, Chenevix-Trench G, Goh C, Sadetzki S, Ramus SJ, Karlan BY, Lambrechts D, Despierre E, Barrowdale D and McGuffog L et al. Association between BRCA1 and BRCA2 mutations and survival in women with invasive epithelial ovarian cancer. JAMA. 2012; 307:38290. | Article | PubMed Abstract | PubMed Full Text

45. Jacquin JP, Jones $S$, Magne $N$, Chapelle $C$, Ellis $P$, Janni W, Mavroudis $D$, Martin $\mathrm{M}$ and Laporte $\mathrm{S}$. Docetaxel-containing adjuvant chemotherapy in patients with early stage breast cancer. Consistency of effect independent of nodal and biomarker status: a meta-analysis of 14 randomized clinical trials. Breast Cancer Res Treat. 2012; 134:903-13. | Article | PubMed Abstract | PubMed Full Text

46. Hayes DF, Thor AD, Dressler LG, Weaver D, Edgerton S, Cowan D, Broadwater G, Goldstein LJ, Martino S, Ingle JN, Henderson IC, Norton L, Winer EP, Hudis CA, Ellis MJ and Berry DA. HER2 and response to paclitaxel in node-positive breast cancer. N Engl J Med. 2007; 357:1496506. | Article | PubMed

47. Lafarge S, Sylvain V, Ferrara M and Bignon YJ. Inhibition of BRCA1 leads to increased chemoresistance to microtubule-interfering agents, an effect that involves the JNK pathway. Oncogene. 2001; 20:6597-606. | Article | PubMed

48. Kennedy RD, Quinn JE, Mullan PB, Johnston PG and Harkin DP. The role of BRCA1 in the cellular response to chemotherapy. J Nat/ Cancer Inst. 2004; 96:1659-68. | Article | PubMed

49. Kriege $\mathrm{M}$, Jager $\mathrm{A}$, Hooning MJ, Huijskens $\mathrm{E}$, Blom J, van Deurzen $\mathrm{CH}$, Bontenbal M, Collee JM, Menke-Pluijmers MB, Martens JW and Seynaeve C. The efficacy of taxane chemotherapy for metastatic breast cancer in BRCA1 and BRCA2 mutation carriers. Cancer. 2012; 118:899-907. | Article I PubMed

50. Kurebayashi J, Yamamoto Y, Kurosumi M, Okubo S, Nomura T, Tanaka K and Sonoo H. Loss of BRCA1 expression may predict shorter time-toprogression in metastatic breast cancer patients treated with taxanes. Anticancer Res. 2006; 26:695-701. | Article | PubMed

51. Shafee N, Smith CR, Wei S, Kim Y, Mills GB, Hortobagyi GN, Stanbridge EJ and Lee EY. Cancer stem cells contribute to cisplatin resistance in Brca1/ p53-mediated mouse mammary tumors. Cancer Res. 2008; 68:3243-50. | Article | PubMed Abstract | PubMed Full Text

52. Stefansson OA, Villanueva A, Vidal A, Marti L and Esteller M. BRCA1 epigenetic inactivation predicts sensitivity to platinum-based chemotherapy in breast and ovarian cancer. Epigenetics. 2012; 7:12259. | Article | PubMed Abstract | PubMed Full Text

53. Tutt A, Robson M, Garber JE, Domchek SM, Audeh MW, Weitzel JN, Friedlander M, Arun B, Loman N, Schmutzler RK, Wardley A, Mitchell G, Earl H, Wickens $M$ and Carmichael J. Oral poly(ADP-ribose) polymerase inhibitor olaparib in patients with BRCA1 or BRCA2 mutations and advanced breast cancer: a proof-of-concept trial. Lancet. 2010; 376:23544. | Article | PubMed

\section{Citation:}

Sharma P, Stecklein SR, Kimler BF, Sethi G, Petroff BK, Phillips TA, Tawfik OW, Godwin AK and Jensen RA. The prognostic value of BRCA1 promoter methylation in early stage triple negative breast cancer. $J$ Cancer Ther Res. 2014; 3:2. http://dx.doi.org/10.7243/2049-7962-3-2 